\title{
Research on Teaching Reform of Physical Education Course in Transitional University of Applied Science
}

\author{
Sheng Liu, Leilei Tian, Kang Zhan \\ College of physical and military education in Jingdezhen Ceramic Institute, Jiang Xi Jingdezhen,
} 333403

\begin{abstract}
Key words: applied undergraduate colleges; university physical education curriculum; teaching reform; teaching content; reform pace
\end{abstract}

\begin{abstract}
Under the influence of the current educational situation, the development speed of applied universities is gradually accelerated, and the overall level of education and teaching has been greatly improved. Under the influence of this background, it is necessary to pay attention to the teaching reform of the course and strengthen the pace of teaching reform under the support of effective measures in order to keep the applied college physical education teaching effect of the transitional period. Based on this, this paper discusses the teaching reform of PE curriculum in the transitional period of applied universities, and promotes the physical education teaching activities to meet the students ' actual needs.
\end{abstract}

\section{Introduction}

It is possible to provide scientific support for the continuous improvement of physical education teaching level and to realize the potential value mining in the practical application of college physical education curriculum, and to promote the application of undergraduate in the transitional period and institutional development. Therefore, it is necessary to take full account of the actual situation of the current PE curriculum teaching in the transitional university in the course of practice, combine the reform requirements under the new situation, and make effective teaching reform from various aspects to ensure the university sports Practical effect of curriculum practice.

\section{The Analysis of the Public Physical Education Curriculum Reform Research Points}

In order to better meet the requirements of the development of the times and enhance the practical application of college physical education curriculum, the application of undergraduate colleges in the transition period should pay attention to the teaching reform of these courses and implement the relevant reform research work. In practice, the teaching of public physical education curriculum research points includes the following:

(A) the analysis of the teaching model of physical education curriculum. In order to meet the requirements of college physical education teaching activities, we need to choose effective teaching mode of PE course of its curriculum reform. In the course of practice, the curriculum of Ci Ning's curriculum should be based on the thought, content, method, evaluation and goal of the curriculum, so as to ensure the effective selection of the teaching model of PE curriculum in the transitional university step by step.

(B) the status quo of the reform of physical education curriculum and the teaching options. Through the in-depth analysis of the present situation of the reform of the current PE curriculum in the current application-oriented undergraduate colleges, it is helpful to find out the relevant countermeasures and help them to maintain the good reform effect. At the same time, it is helpful to promote the development of students ' personality and enrich the content of college physical education teaching, and gradually improve the overall teaching quality and efficiency of the university PE curriculum reform teaching research work, and pay attention to the " people - oriented ".

(C) the study of college physical education curriculum evaluation and credit system, curriculum 
system. Through the in-depth analysis of the actual situation of the applied undergraduate colleges, the credit system and the college physical education curriculum teaching effectively combine to be able to inject more vitality into the reform process. At the same time, it is helpful to optimize the reform mode and meet the requirements of the sustainable development of PE teaching in applied colleges and universities, and pay attention to the scientific evaluation of the teaching of college physical education in the process of reform. In addition, colleges and universities should pay attention to the reasonable sett of the goal of " physical education and health " in the reform of college physical education curriculum, and realize the diversification of teaching content with " sports and health " with the common support of reform initiative and practical experience. Students need to improve their physical fitness at the same time the overall health level will gradually increase [1].

The above content objectively reflects the current focus of the current public physical education curriculum reform research. Therefore, in the course of the reform of college physical education curriculum, the applied undergraduate colleges should fully play their own functions, and carry on the thorough analysis and the effective treatment to the problems in the reform research, and make the teaching reform process have rich reality significance, and promote the transformation and development of local colleges and universities to meet the diversified needs of physical education in applied colleges and universities.

\section{The Application of Undergraduate Colleges and Universities in Transition Period of Physical Education Curriculum Reform Problems and Contradictions}

\subsection{The Contradiction Between Supply and Demand in College Physical Education Curriculum}

In the course of realizing the teaching and reform goal of lifelong physical education, some of the applied undergraduate colleges have failed to highlight the student's subjective position in the teaching reform of physical education curriculum, so that the physical education teaching activities under the reform initiative can not meet the students ' actual needs. In the past, the students will take the initiative to participate in the enthusiasm for college physical education teaching activities, and the related PE teaching plan is difficult to further advance, invisible will hinder the development of applied undergraduate institutions, weakening its competitiveness in the teaching reform of physical education curriculum.

\subsection{The lack of Teaching Resources, Curriculum Teaching Methods Lack of Innovation}

Under the influence of the mode of expanding enrollment, the application of undergraduate education in colleges and universities makes the effective use of the existing PE teaching resources prominent : the process of teaching resources is also a negative impact on the university physical education teaching activities. In this context, the application of undergraduate colleges in the transition period of physical education curriculum reforms need to pay attention to the insufficient use of physical education resources to ensure the smooth implementation of its teaching plan. At the same time, due to the lack of innovative teaching methods of college physical education curriculum, the overall level of education and teaching has been reduced, it is difficult to mobilize the enthusiasm of students to participate in physical education teaching activities, and objectively explain the necessity of the reform of the university sports curriculum teaching method [2].

\subsection{The Problems in the Teaching Model, Curriculum Optimization and Evaluation}

As the application of undergraduate institutions of physical education teaching model is relatively simple, whether in the elective course model or teaching activities arrangements, it is difficult to stimulate learning to participate in physical education activities more enthusiasm. At the same time, because some of the current application-oriented undergraduate institutions there is unreasonable allocation of physical education curriculum, teaching evaluation is lacking scientific problems, making its reform objectives difficult to achieve, need relevant personnel in the university physical 
education curriculum reform research to give these questions more attention.

\section{The Related Initiatives to Strengthen the Application of Undergraduate Colleges and Universities During the Transition Period of Physical Education Curriculum Reform}

\subsection{To consider the actual needs of students, focus on physical education curriculum reconstruction the course of teaching reform of college physical education}

The application of undergraduate colleges can take full account of the actual needs of students, pay attention to the reconstruction of their physical education curriculum, and gradually realia the goal of curriculum reform. (1 ) focus on the implementation of university physical education curriculum projects, focus on the implementation of the curriculum of physical education, (2) pay attention to the implementation of the university physical education curriculum, For students in sports courses to provide more choices to meet their actual needs while improving the efficiency of college physical education teaching reform [3].

\subsection{Strengthen the "School-Based Brand Curriculum" to Achieve the Objectives of Physical Education Curriculum Reform}

In the course of practice, in order to put forward the school-based physical education curriculum, improve the efficiency of the utilization of physical education teaching resources and enhance the innovation of its teaching methods, the local colleges and universities should strengthen the construction of the school-based brand curriculum in the reform of college physical education curriculum in the transition period. The detailed is following:(1) In the process of setting up physical education curriculum, the characteristics of physical education teaching in applied colleges should be highlighted, and the efficiency of resource utilization in the implementation of education and teaching plan should be improved.(2) pay attention to the setting of the new physical education teaching project, and make the teaching and learning plan of the teaching and learning program in the course of the development of the physical education curriculum. To achieve the continuous expansion of physical education courses, the implementation of these initiatives is conducive to the realization of college physical education curriculum reform objectives.

\subsection{Optimize the Teaching Model and Evaluation Methods, and Enhance the Rational Allocation of Curriculum Resources}

In order to maintain the effect of the reform of physical education curriculum in the transitional period, it is necessary to pay attention to the optimization of teaching mode and evaluation mode, and to enhance the rationality of PE curriculum resource allocation. (1) According to the requirements of college physical education curriculum reform and the content of textbook layout, optimize the existing PE teaching mode and improve the attractiveness of its teaching activities; (2) combine the requirements of physical education teaching activities, configure the relevant teaching resources, and focus on the diversification of teaching evaluation methods of flexible use [4].

\section{Concluding remarks}

To sum up, the flexible use of these different measures can provide the necessary support for the reform of college PE curriculum in the transitional period of applied universities, enhance the applicability of college physical education curriculum, and lay a solid foundation for students' physical quality improvement and comprehensive development. Therefore, the future application of undergraduate institutions should take full account of their own actual situation and the current situation changes, to give its transitional college physical education curriculum reform more attention, and in the scientific reform measures and the corresponding work under the joint action, to maintain its good teaching reform effect.

\section{References:}

[1] Wu Guang, Du Zhahui.From the perspective of the main body of the university physical 
education curriculum reform [J]. Chongqing and the world (academic version), 2016, (10).

[2] Zhu Yongsen. Sunshine sports under the university physical education curriculum reform practice [J]. Journal of Jilin Radio \& Television University, 2012, (06).

[3] Ke Haibao. College physical education curriculum reform [J]. Test Weekly, 2016, (70).

[4] Wang He. Review and Reflection on Teaching Reform of College Physical Education Teaching Course [J]. Science and Technology Outlook, 2014, (24). 